\section{Polymerase chain reaction chlamydia trachomatis examination in nonspecific genital infection patients}

Dian Pertiwi Habibie, Dwi Murtiastutik,

Department of Dermatology-

Venereology, Dr. Soetomo Teaching

Hospital / School of Medicine,

University Airlangga, Surabaya,

Indonesia

\begin{abstract}
Nonspecific genital infection (NSGI) is an inflammation of urethra, rectum, or cervix that caused by nonspecific bacteria. Chlamydia trachomatis is known as the most causal organism of NSGI, usually mild (mucopurulent discharge) or asymptomatic, and if untreated it can cause serious complication such as pelvic inflammatory disease that leads to infertility in women. The diagnosis of Chlamydia trachomatis needs an advanced method, such as polymerase chain reaction (PCR). PCR has high sensitivity and specificity, and endocervical swab is specimen of choice that also has high sensitivity and specificity to diagnose Chlamydia trachomatis. This research aims to evaluate if Chlamydia trachomatis is the most causal organism of NSGI by PCR Chlamydia trachomatis using 201bp primers. Eighteen NSGI married patients who came to outpatient clinic were evaluated from endocervical swab. The result demonstrated that $16,67 \%$ from eighteen NSGI patient positive Chlamydia trachomatis. The low incidence of Chlamydia trachomatis in low risk population such in this study need further study, the cause of NSGI needs to be known certainly so the exact treatment can be given.
\end{abstract}

\section{Introduction}

Non specific genital infection (NSGI) is an inflammation of urethra, rectum, or cervix that caused by non specific bacteria. ${ }^{1}$ The prevalence of NSGI at outpatient clinic Dr. Soetomo General Hospital in 2016 is 47 $(1,25 \%)$ cases from 3.753 all new dermato and venerology cases while percentage of NSGI is $17,23 \%$ from 273 total new cases in sexual transmitted disease division. The diagnose of NSGI is established by detail anamnesis, clinical examination for the sign of urethritis or mucopurulent exudate from cervix, Gram staining from cervical swab which is polymorphonuclear more than 30 in wide microscopic field and all other specific bacteria or fungal have already excluded such as diplococcic Gram negative bacteria (Neisseria gonorrhea), Trichomonas vaginalis, candidiasis vulvovaginalis and



Chlamydia trachomatis is known as the most organism causing NSGI is an obligate intracellular bacteria that grow and replicate in eukaryotic host cells. The development cycle is biphasic with morphologically cell types include the infective particles (elementary bodies) and the reproductive particles (reticulate bodies). Chlamydia trachomatis infected more than 100 million people every year in worldwide by sexual transmission. Genital Chlamydia trachomatis infection affected women mostly asymptomatic that the patients are not aware and do not seek for treatment. The Chlamydia trachomatis infection that not treated will cause serious complication in women such as pelvic inflammatory disease which can lead to infertility and ectopic pregnancy. ${ }^{1-3}$ To establish the diagnose Chlamydia trachomatis infection can not only with conservational microscopy laboratory. The absence of peptidoglycan in Chlamydia trachomatis explains why the organism is not seen with standard Gram's staining.

The development of tests based on nucleic acid amplification technology (NAAT) has been the most important advance to diagnose Chlamydia trachomatis because nucleic amplification is highly sensitive its capablity of detecting as little as a single gene copy and also highly specific. It does not need invasive sampling and it is a critical advantage to screen infection since the majority of chlamydial infection in women are asymptomatic. DNA amplification tests using noninvasive sampling have been reported to improve screening test that use invasive sampling by at least $30 \%$ increase in sensitivity. The most widely known of the DNA amplification technique is polymerase chain reaction (PCR) ${ }^{4}$

Diagnostic methods based on PCR are the most advanced tools for Chlamydia trachomatis. Several recent studies demonstrated that PCR has higher sensitivity and specificity superior to the other methods. PCR is based on amplification of a DNA sequence that is highly specific for infectious agent. Such large amount of DNA can easily detected and this is the prime reason why PCR is more sensitive than the other methods, diagnostic sensitivity of PCR based method for Chlamydia trachomatis is $90-100 \%$. PCR is directly detect the presence of bacterium by identifying specific DNA in the bacterium. PCR amplify and detect a sequence highly specific for the
Correspondence: Dian Pertiwi Habibie, Department of Dermatology-Venereology, Dr. Soetomo Teaching Hospital/School of Medicine, Universitas Airlangga, Surabaya, Indonesia. Gayungsari Timur II/E-2, Surabaya, East Java, Indonesia.

Tel.: +6281330220023.

E-mail: dheyhabibie@gmail.com

Key words: Nonspecific genital infection, Chlamydia trachomatis, Ppolymerase chain reaction.

Acknowledgements: This study was supported by the RSUD. Dr. Soetomo Teaching Hospital/Medical Faculty of Airlangga University and Institute of Tropical Disease Airlangga University Surabaya.

Contributions: the authors contributed equally.

Conflict of interest: the authors declare no potential conflict of interest.

Received for publication: 1 February 2019. Accepted for publication: 13 February 2019.

This work is licensed under a Creative Commons Attribution-NonCommercial 4.0 International License (CC BY-NC 4.0).

CCopyright D.P. Habibie et al., 2019 Licensee PAGEPress, Italy

Dermatology Reports 2019; 11(s1):8055 doi:10.4081/dr.2019.8055

bacterium that make PCR method has high specificity. PCR specificity to diagnose Chlamydia trachomatis is $99,6 \%$. PCR is a rapid diagnostic test, it can be processed in $5-6$ hours and the result is highly reliable. Samples in need for PCR can be from all sources, it may use noninvasive samples as well. 5,6

\section{Materials and Methods}

This research is descriptive observational study, using cross sectional method to evaluate if Chlamydia trachomatis is the most organism causing NSGI. Samples were all NSGI patients that came to dermatovenerology outpatient clinic Dr. Soetomo general hospital Surabaya in sexual transmitted disease division and were taken consecutively in 3 months (June - August 2017). Inclusion criteria include women with IGNS who are married. Women in menstrual period, pregnant and diagnosed with mixed infection are excluded.

Informed consent was obtained from the patients before procedure. All women patients who came to outpatient clinic with mucopurulent discharge were performed an 
internal examination, endocervical swab is collected twice at the same time, one sample for the gram staining, wet preparation and $\mathrm{KOH}$ examination. The other endocervical swab sample is collected in to tube filled with phosphate buffer saline (PBS). Once the result from gram staining, wet preparation and $\mathrm{KOH}$ examination determined if it is found polymorphonuclear leucocyte more than 30 in wide microscopic field and the specific organism such as Neisseria gonorrhea, Trichomonas vaginalis, candidiasis vulvovaginalis and bacterial vaginosis are already excluded the diagnose of NSGI is established.

The samples in tube filled with PBS are stored in cool place with temperature of refrigerator and the samples were delivered in cooler bag with ice gels inside to keep the samples in cool temperature. The samples then brought to Institute of Tropical Disease (ITD) in order to perform PCR examination, the PCR tool used in this study was MyQ-2 (Bio Rad). The primer used in this study was 201bp targeted in endogenous plasmid CTP1 (forward strand: 5'-TAG TAA CTG CCA CTT CAT CA-3') dan CTP2 (reverse strand: 5'-TTC CCC TTG TAA TTC GTT GC-3'). Ethical clearance had been approved for this study by Ethical Committee in RSUD Dr. Soetomo general hospital.

\section{Results}

This research involved 18 women diagnosed with NSGI in dermatovenerology outpatient clinic - sexually transmitted disease division RSUD Dr. Soetomo general hospital Surabaya. All patients meet the requirement and are willing to participate in this research by signing informed consent and information for consent. The result in this study, Chlamydia trachomatis is detected in $3(16,67 \%)$ NSGI patients, the rest of $83,33 \%$ were negative. Table 1 and Figure 1 show the percentage of patients with negative and positive PCR Chlamydia trachomatis.

\section{Discussion}

Based in literature Chlamydia trachomatis is the most $(30 \%-50 \%)$ causal organism of NSGI. Genital Chlamydia trachomatis infection in women majority is asymptomatic and when there is any symptoms, it is mild but the complication may serious when it is untreated. ${ }^{1,7}$ It is important to use sensitive and specific molecular assay like PCR to prevent under diagnosed of genital chlamydial infections. ${ }^{8}$

NAAT has been the most important

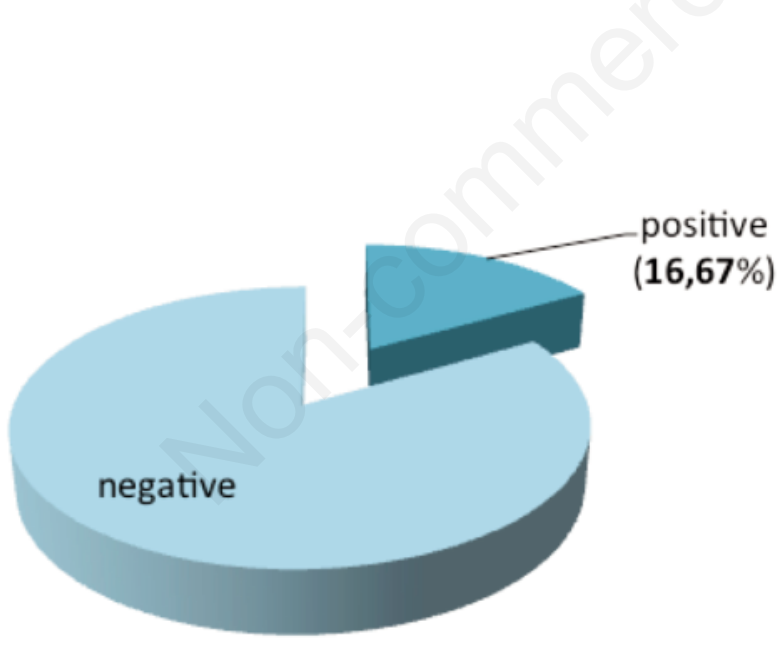

Figure 1. Profile result of Polymerase chain reaction Chlamydia trachomatis in Nonspecific genital infection patients.

Table 1. Profile result of Polymerase chain reaction Chlamydia trachomatis Nonspecific genital infection.

\begin{tabular}{lcc}
$\begin{array}{l}\text { Profile of polymerase chain reaction } \\
\text { Chlamydia trachomatis }\end{array}$ & Patient & $\begin{array}{c}\text { Percentage } \\
(\%)\end{array}$ \\
Positive & 3 & 16,67 \\
Negative & 15 & 83,33 \\
\hline Total & 18 & 100 \\
\hline
\end{tabular}

advancement in chlamydial infection diagnosis since in vitro cell culture techniques replaced the yolk sac for culture and isolation of the organism from clinical specimens. This technique detect nucleic acid targets that not depend on either viability or an intact state of the target organism for positive result. NAATs also known as the most sensitive tests for the screening and diagnosis of chlamydial infection of the genital tract. ${ }^{9}$ NAATs include PCR and ligase chain reaction (LCR). PCR test utilize two synthetic oligonucleotide primers with sequences that are completing to the flank regions of a specific DNA segment present in the target organism. ${ }^{4}$ This study use PCR and the primers used for amplifying a 201 bp fragment of Chlamydia trachomatis endogenous plasmid were CTP1 (forward strand: 5'-TAG TAA CTG CCA CTT CAT CA-3') dan CTP2 (reverse strand: 5'-TTC CCC TTG TAA TTC GTT GC-3'). The specimens used in this study were from endocervical swab which is the appropriate for women undergoing speculum examination which has $100 \%$ sensitivity and $98 \%$ specificity. ${ }^{6,10}$

The result of this study performed in Dr. Soetomo general hospital Surabaya is 3 $(16,67 \%)$ of 18 NSGI patients were detected Chlamydia trachomatis with PCR using endocervical swab samples. This is consistent with previous studies conducted in Padang, from June 2015 - April 2017 that shows the result of PCR Chlamydia trachomatis detected in $10 \%$ of 39 NSGI patients. ${ }^{11}$

\section{Conclusions}

Chlamydia trachomatis was known to be the most causal organism of NSGI. The study that perform in low risk population such as in this study may result in low detection of Chlamydia trachomatis. Detection of Chlamydia trachomatis needs an advance technique, to date PCR based method is the most reliable methods for detection of chlamydial infections because its high sensitivity and specificity which are very important characteristic for a laboratory diagnostics. Further study of causal of NSGI in low risk population needs to be done, It is important to know the cause of NSGI certainly so the exact treatment can be given.

\section{References}

1. Daili SF, Indriatmi W, Zubier F, Nilasari $\mathrm{H}$, editors. Dalam: Infeksi genital non- 
spesifik, pedoman praktis diagnosis dan tatalaksana infeksi menular seksual. Jakarta : Kementrian kesehatan republik Indonesia. 2015.

2. Moodley S. Laboratory diagnosis and identification of Chlamydia trachomatis. In: Méndez-Vilas A. The battle aginst microbial pathogens: basic science, technological advances and educational programs. Badajoz: Formatex research center. Vol 2. 2015. h.1036-43.

3. Lanjouw E, Ouburg S, de Vries HJ, et al. European guideline on the management of Chlamydia trachomatis infections. Int J STD AIDS 2015;1-16.

4. Black CM. Current methods of laboratory diagnosis of Chlamydia trachomatis infections. Clin Microbiol Rev 1997; 10:160-84.

5. Obradović D. PCR (Polymerase chain reaction) in detection of Chlamydia trachomatis and the other methods - a comparative survey. Natura montenegrina 2007;6:131-6.

6. George JA, Panachatcharam TS, Paramasivam R, et al. Evaluation of diagnostic efficacy of PCR methods for Chlamydia trachomatis infection in genital and urine specimens of symptomatic men and women in India. Jpn J Infect Dis 2003;56:88-92.

7. Qayum M, Khalid-bin-Saleem M. Prevalence of Chlamydia trachomatis among asymptomatic women. J Ayub Med Coll Abbottabad 2013;25(1-2):2830 .

8. George JA, Panachatcharam TS, Paramasivam R, et al. Evaluation of diagnostic efficacy of PCR methods for Chlamydia trachomatis infection in genital and urine specimens of symptomatic men and women in India. Jpn J Infect Dis 2003;56:88-92.

9. Malhotra M, Sood S, Mukherjee A, et al. Genital Chlamydia trachomatis: An update. Indian J Med Res 2013;138: 303-16.

10. Britsih association for sexual health and HIV. Chlamydia trachomatis UK testing guidelines.

11. Sari M, Isramiharti, Anun Q. Uji diagnostik pemeriksaan spesimen urin pada Infeksi genital non spesifik pada wanita yang disebabkan Chlamydia trachomatis dengan metode Polymerase chain reaction. Program Pendidikan Dokter Spesialis Fakultas Kedokteran Universitas Andalas. 2017. Thesis, abstract available from: scholar UNAND. 